\title{
ACCESSIBILITY TO MICROCREDIT BY CHINESE RURAL HOUSEHOLDS
}

\author{
Xia, Li \\ PhD Student, Faculty of Commerce, Department of Accounting, Economics and Finance, PO Box \\ 84, Lincoln University, Canterbury, New Zealand, \\ Tel: 64-3-325-2811, Email: judy.li@lincolnuni.ac.nz
}

\begin{abstract}
Christopher, Gan
Associate Professor, Faculty of Commerce, Department of Accounting, Economics and Finance, PO Box 84, Lincoln University, Canterbury, New Zealand, Tel: 64-3-325-2811,Email: Christopher.Gan@Lincoln.ac.nz.
\end{abstract}

\author{
Baiding, Hu \\ Senior Lecturer, Faculty of Commerce, Department of Accounting, Economics and Finance, PO \\ Box 84, Lincoln University, Canterbury, New Zealand, \\ Tel: 64-3-325-2811, Email: Baiding.Hu@Lincoln.ac.nz
}

\begin{abstract}
This paper examines key factors influencing the accessibility of microcredit by rural households in China. The empirical approach is built upon logistic regression and data are collected through a household survey. A total of twelve household-level factors are identified as determinants in households' access to microcredit and the results indicate that households' accessibility to microcredit can also be impaired by the supply-side factors. The paper concludes that households should increase credit demand to expand their access to microcredit. In addition, microcredit institutions should improve lending schemes and loan products to better suit the diversified needs of the rural population.
\end{abstract}

JEL Codes: G21, O17, Q14

Keywords: microcredit, accessibility, rural households, China

\section{Introduction}

Credit has been increasingly accepted as a powerful instrument to help poor people invest and break out of 'vicious cycle' of poverty because it has the potential of improving the users' incomes and savings, and consequently, enhancing capital accumulation and reinforcing high incomes (Atieno, 2001). Despite the importance of credit in helping the poor to improve their welfare, poor people are excluded from formal financial system and such exclusion ranges from partial exclusion in developed countries to full or nearly full exclusion in less developed countries (LDCs) (Brau and Woller, 2004). Traditional financial institutions (FIs) are reluctant to serve the poor mainly because poor people fail to meet the selection criteria such as the requirement of physical collateral set by FIs. The perceived high risks and costs arising from processing and servicing unsecured small loans also make FIs shy away from financing the poor, mainly due to the concern of financial viability. Lacking access to formal credit, most poor and low-income people continue to rely on meagre self-finance or informal credit, which limit their ability to actively participate in and benefit from the development process.

As a response to the failure of formal financial sector in catering to the poor's credit needs, microcredit was first initiated in Bangladesh by Professor Muhammad Yunus in the late 1970s and has gained a significant growth over the past 20 years. Microcredit extends small loans (micro loans) to people who are traditionally considered unbankable to generate income and spur entrepreneurship. Compared to traditional lending, microcredit has its own vivid characteristics, such as targeting the poor, collateral-free and joint liability (or group lending). By removing obstacles in traditional lending (such as collateral requirement), microcredit largely facilitates the poor's access to institutional credit when they need financial support. 
This gives the poor a means of better living, either temporarily (such as smoothing seasonal consumption) or in the long run (such as creating employment opportunities). Due to its great potentials such as reducing poverty, microcredit has been promoted as an efficient development intervention programme by many countries.

Like most Asian developing countries, the majority of the poor population in China dwell in rural areas. There are 76 million 'relatively' poor people surviving on less than a dollar per day in rural China and the rural population living in both 'absolute poverty' and 'relative poverty' accounts for $11 \%$ of the total rural population. Moreover, the rural incomes are just 30\% of the urban average, which presents a wide gap between the rural and urban living standard (Gale, Lohmar and Tuan, 2005). Inability to acquire formal credit support has constrained poor farmers' ability to expand their production and improve their living conditions. The Chinese collective land-ownership system has prevented farmers from accessing traditional credit from formal FIs because farmers cannot use land as collateral, a necessary requirement in traditional lending. However, farmers need credit support to meet their living needs including the purchase of durable goods, daily consumption, and festivals and ceremonies. More importantly, accessing affordable agricultural credit allows farmers to adopt new technology, which provides them with potential economic opportunities to improve production and income. Failing to access formal credit, most farmers have to resort to informal borrowings which are typically offered at higher interest rates. Despite the high interests charged by the informal lenders, approximately $50 \%$ to $60 \%$ of rural households in China still rely on informal credit for their consumption and production (Han, 2004). However, the high interest of informal loans have increased the farmers' indebtedness and further kept most of the households trapped in poverty.

Since China agriculture is dominated by small farms and farmer households are the basic units of agricultural production ${ }^{1}$, limited access to formal credit has long been blamed as a key restraint in expanding farmers' production and improving their livelihood, which potentially leads to the stagnant growth of the rural economy (Park, Ren and Wang, 2004; Cheng and $\mathrm{Xu}, 2004)$. With a widening gap between rural and urban living standards and the growing awareness of the significance of agriculture, the Chinese government carried out various agriculture-support policies focusing on farmer lending to solve 'three rural problems', namely raising rural incomes, improving agricultural production, and developing rural areas.

\footnotetext{
${ }^{1}$ Before the economic reform initiated in the late 1970s, the Chinese agricultural economy was characterised as collective economy, of which the basic production unit was production team. The most successful reform since 1970s was the shift from the collective system to the household responsibility system (HRS) which restored the primacy of individual household as the basic unit of production in rural China.
}

Under the circumstances, microcredit was introduced into China as part of the government's poverty alleviation strategies in the mid-1990s, aiming to ameliorate rural poverty through a financially sustainable approach. Different types of organisations have been involved in implementing microcredit programmes in China, including non-governmental organisations (NGOs) or quasi-official organisations, government agencies, and formal rural financial institutions (RFIs) such as the Rural Credit Cooperatives (RCCs). In terms of different providers, China microcredit programmes can be categorised as three types. The first type includes experimental microcredit projects provided by NGOs and quasiofficial organisations, aiming to explore the feasibility, operating capabilities and policy implications of microcredit in China; the second type focuses on poverty alleviation carried out by government agencies; and the third type centres on RCCs with the purpose of minimising credit constraint in the rural areas of China (Du, 2005, 2004). Since implementing microcredit programmes in 2000 , RCCs have quickly expanded their microcredit activities with an extensive network in rural areas and take the leading role in popularising and formalising microcredit in China.

With the implementation of microcredit, China has boosted lending to farmers in recent years. For example, the balance of outstanding agricultural loans by RCCs has been more than doubled between 2001 and 2005, with a balance equivalent to $\$ 127$ billion in 2005 (Gale and Collender, 2006). Under the agricultural lending support from the People's Bank of China (PBC) which is the main funding source for RCCs' microcredit programmes, RCCs have substantially developed their microcredit programmes and evolved as the largest microcredit providers serving the grassroots level in rural China. However, in spite of the strong efforts made by the Chinese government to facilitate credit access in rural areas, there are evidences showing that a large number of poor households who are regarded as marginalised people in their villages do not have access to microcredit because of their weak social and economic conditions. In addition, women in rural China are still disadvantaged in accessing any form of formal credit including microcredit and in some occasions, they have to use their husbands' names to apply for microcredit loans (Han, 2004; Unger, 2002). A relevant question arises: What kind of factors, household-level or institution-level, are likely to influence rural households' accessibility to microcredit in China? Unfortunately, few empirical studies have been conducted in this regard.

This paper aims to empirically analyse households' accessibility to microcredit to identify the key factors affecting the access to microcredit. The microcredit programme studied in this paper is carried out by the RCC, the largest microcredit provider in China. Outperforming the programmes operated by NGOs and government agencies in terms of outreach and financial sustainability, RCC's microcredit programme is the most prevailing type in rural China. The remainder of the paper is organised as follows. Section 2 provides an 
overview of rural credit market in China. Section 3 discusses the research methodology and data collection. The research results are discussed in Section 4. Section 5 concludes the paper.

\section{Rural Credit Market in China}

The rural credit market in China share similar features with those found in many other developing countries: the market is fragmented, where formal and informal credit sources coexist; formal credit is highly regulated but difficult to access by rural households; informal lending is more readily accessed but always appears to be clandestine and considered illegal (Jia, Heidhues, and Zeller, 2007). Since the economic reform initiated in the late 1970s, there has been a gradual improvement in China's rural financial system, aiming to gear the system towards meeting the diversified financial needs of the rural and agricultural sectors. The current formal rural financial sector is characterised as a "three-tier system", composed of a state-owned commercial bank (Agricultural Bank of China), a government policy-based bank (Agricultural Development Bank of China), and Rural Credit Cooperative (RCC). Each of the three RFIs plays a unique role in providing lending support to the agricultural sector and rural households in China.

The Agricultural Bank of China (ABC) is the largest commercial bank involved in agriculture. Loans from the ABC include specialised agricultural loans (such as comprehensive development and subsidiary businesses in grain, oil, and cotton), conventional agricultural loans (such as farming, forestry, livestock, fisheries, and the processing of agricultural products), loans for township and village enterprises (TVEs), loans for rural supply and marketing co-operatives (SMCs), and for basic rural facilities construction. As a policy bank, the Agricultural Development Bank of China (ADBC) primarily operates the agriculture-related financial businesses regulated by the State, such as the supply and management of funds for the procurement of selected agricultural products. Specifically, loans (above 90\%) from the ADBC are issued to the stateowned enterprises for the purchase, storage and marketing of important agricultural products including grain, cotton and oil (Han, 2004; He and Guo, 2004; Druschel, 2002).

The RCCs are financial cooperative institution with rural labourers as share-holding members and operate at either village-level or township-level. The townshiplevel RCCs can run both savings and credit businesses but the village-level RCCs are only allowed to take in deposits from villagers, plus collecting loan applications and submitting them to township-level RCCs for approval. Since the start-up capital of RCCs comes from farmers $(80 \%$ or more of RCCs' funding comes from farmers' savings deposits), RCCs have a close relationship with farmers and loans provided by RCCs principally target rural households (Druschel, 2002; Guo and Lei, 2000). Loans issued to rural households are mostly in the form of microcredit, giving key support to crop production, fish breeding, raising animals, as well as children's education and daily consumption (PBC, 2001).

The three major financial institutions within the system, i.e., ABC, ADBC, and RCC, perform their own functions in regards to commercial, policy, and cooperative finance. The Chinese government has placed high emphasis of the important role played by agriculture in the national economy and realised that agricultural credit is an efficient way of channelling more cash into the rural economy to boost production and raise rural incomes. Encouraged by the government, the RFIs have substantially increased the agricultural lending during the past two decades, manifested by the total loan amount granted by all RFIs rising from 45.4 billion yuan in 1979 to 3238.7 billion yuan in 2000. In particular, the total amount of RCCs' loans (which are issued mostly towards rural households) rose from 4.8 billion yuan in 1979 to 1048.9 billion yuan in 2000, indicating a 218-fold increase (Han, 2004).

Despite the evident achievements in agricultural lending made by the RFIs, the RFIs have been heavily criticised for being unable to satisfy the various credit needs of the rural households in China. The access to institutional credit by the rural households remains constrained. Such constraint can be partly attributed to the insufficient credit supply by RFIs in rural China. The credit insufficiency mainly arises from the lack of RFIs providing financial services to farmers. Although the $\mathrm{ABC}$ and $\mathrm{ADBC}$ both serve the rural areas, they mainly focus on agricultural product processing companies and large-scale agricultural development projects run by the state government, and do not issue loans to farmers (Druschel, 2002). As a result, the RCC is the only RFI serving the grassroots of rural society with the provision of financial services, especially after other financial institutions such as the $\mathrm{ABC}$ have largely withdrawn their financial services from rural areas to target more profitable operations in urban areas. However, there are only about 40,000 RCCs across the country and the credit supply by RCCs is inadequate to meet the considerable credit demand required by the enormous rural households in China (Gale and Collender, 2006; Ma, 2004). The insufficient credit supply is further exacerbated by the increasing financial losses of RFIs resulted from the capped lending rates set by the $\mathrm{PBC}$, which has crippled the RFIs' ability to provide credit support to rural households. The low lending rates usually cannot generate sufficient revenues for RFIs to make profit given the high transaction and operational costs incurred in lending to farmers (Cheng and Xu, 2004).

Apart from the shortage of credit supply, households' accessibility to formal credit has been severely weakened by the lending terms and procedures set by the RFIs. Collateral requirement is the most frequentlymentioned obstacle that prevents poor households from accessing formal credit. To address the problems of adverse selection and moral hazards arising from asymmetric information between banks and borrowers, banks usually attach collateral requirements to loans. Collateral is used to assist in determining creditworthiness, as well as solving the incentive and 
enforcement problems (Klein, Meyer, Hannig, Burnett, and Fiebig, 1999). Such collateral requirement becomes more stringent when the borrower is resourcepoor.

Land is always a preferred form of collateral in formal agricultural lending. However, farmers in China do not have the ownership of the land on which they farm. Instead, farmland is owned by villages and distributed on an egalitarian basis among village members. The lack of land ownership equals the lack of proper collateral, which makes formal credit inaccessible to China's farmers (Gale and Collender, 2006; Unger, 2002). In addition to the lack of appropriate collateral, the high borrowing costs borne by the Chinese farmers keep them away from formal credit. Other than loan interest, farmers' borrowing costs consist of the time spent on travelling and on loan applications, gifts and kickbacks to loan officers, and the membership fees. The long and complicated loan application procedures have often dampened farmers since it tends to jeopardize productive investment opportunities when quick credit is required. It is also quite common for loan applicants to invite loan officers to banquets and/or give kickbacks directly to loan officers for loan approvals. In the case of RCCs, households have to pay membership fees (usually $\$ 7$ to $\$ 20$ ) to RCCs before they can lodge their loan applications (Cheng and $\mathrm{Xu}$, 2004).

Failing to secure credit support from formal financial institutions, the majority of poor farmers have to fall back on informal sources to meet their credit needs. Informal credit in China includes loans obtained from non-commercial sources such as friends, relatives and acquaintances, and loans from private lending and borrowing organisations (PLBs), such as professional moneylenders, traders, pawnbrokers and usurers. PLB is the dominant source of informal finance in rural China (Han, 2004; Cheng and $\mathrm{Xu}, 2004$ ). Tilakaratna (1996) estimates that the share of informal loans in the total borrowing by the rural sector in developing countries ranges from 30 percent to more than 80 percent. In the case of China, informal credit has become the main source of credit among the rural population, accounting for more than $70 \%$ of the farmers' total borrowing (Ma, 2004). While the farmers' credit needs for daily consumption can be met by borrowing from their friends and relatives free of charge, the needs for production are largely met by borrowing from PLBs with high interest rates (Wang and Liu, 2005). Compared to formal financing, informal financing possesses some advantages, such as close personal relationships with clients, flexibility, rapidity and low transaction costs, which make informal finance either the exclusive or the preferred credit source in rural areas despite exploitative interest rates (Cheng and $\mathrm{Xu}, 2004$ ). However, informal lenders normally depend on personal funds and the limited resources restrict the extent to which the informal lenders can effectively and sustainably satisfy the credit needs of their borrowers. The limited credit supply by informal lenders then leads to either severe credit constraints or usurious loans for some borrowers (Atieno, 2001).
Informal finance remains controversial in China's rural financial construction. On the one hand, there are opponents who traditionally regard informal finance as a violation of normal financial discipline in China despite its contribution to meeting farmers' urgent financial needs. The evidence supporting such argument is that the Chinese government never gives overt recognition to the legal existence of the informal sector and the development of informal credit is generally clandestine and out of the government's supervision (Jia et al., 2007; Ma, 2004). The opponents suggest excluding informal credit from rural financial markets by improving the lending operations of formal financial institutions to provide more loans in favour of rural households, which is crucial in establishing a sound rural financial system and maintaining the sustainable development of China's rural economy. However, advocates of informal finance contend that the existence of informal credit in China reflects the imperfections of China's formal rural financing system, which is characterised as unable to meet the diverse capital demands of the rural households. If no changes are made in the current situation, the persistence of informal credit will be both necessary and rational in view of the credit facilities provided to the farmers (Ayyagari, Kunt, and Maksimovic, 2008; Guo and Lei, 2000).

\section{Research Methodology and Data}

\section{Conceptual framework and empirical model}

Household's accessibility to credit can be defined as the ability to borrow from different sources of credit (Diagne and Zeller, 2001; Diagne, 1999). Evans, Adams, Mohammed, and Norris (1999) present a conceptual framework in analysing factors that affect households' accessibility to microcredit in Bangladesh, in which both household-related factors and programme-related factors are taken into account. Similarly, Vaessen (2001) examines households' accessibility to rural credit in Northern Nicaragua by analysing both demand-side (households) factors and supply-side (lenders) factors. This paper employs Evans et al.'s (1999) conceptual framework to investigate households' accessibility to microcredit in rural China by focusing on the microcredit programme implemented by the Rural Credit Cooperatives (RCCs).

Household-related factors (such as income, occupation, age, education) are hypothesised to affect households' demand for microcredit, which can directly influence households' accessibility to microcredit. This is because households' access to a certain type of credit can be conceptualised as a sequential decision making process that is initiated at the demand side (Zeller, 1994). In addition to household-related factors, there are programme-related (supply-side) factors influencing the households' access to microcredit too. For example, Umoh (2006) argues that the inaccessibility to credit is generally created by the lending policies of financial institutions, which can be manifested by complicated application procedures, specified minimum loan amount and prescribed loan purpose. In addition, some features unique to 
microcredit programmes can also constrain households' access to microcredit, including membership requirement, self-selected credit group, and group lending (see for example, Maes and Foose, 2006; Evans et al., 1999). Institutional incentives such as achieving repayment target and ensuring programme financial viability may induce the lenders shy away from lending to households who are or appear to be risky borrowers (Maes and Foose, 2006; Evans et al., 1999).

Due to the supply-related factors, households who have a demand for microcredit may access microcredit or stay frustrated by denial. Therefore, household-related factors and programme-related factors, singly or in combination, can work to impact households' accessibility to microcredit. This paper attempts to measure households' accessibility to microcredit by empirically examining the influence of household factors on the probability of securing micro loans from the RCCs. Data used in the empirical analysis includes primary data collected from a rural household survey in China (data collection is discussed in the subsequent section). The influence of institution-level factors (i.e., supply side factors) on households' accessibility to microcredit is examined descriptively with qualitative information collected from the household survey. Furthermore, this paper assumes that rural households in China prefer microcredit to other credit types such as formal credit and informal credit when they need to borrow, due to the merits of microcredit such as collateral free and affordable interest rates (RCC's micro loans are provided at commercial rates).

Previous studies have identified a variety of householdlevel factors that influence households' ability to access a certain type of credit. For example, Mohamed (2003) conducted an empirical study examining the accessibility to formal and quasi-formal credit by farmers in Zanzibar, where socio-economic characteristics of rural households such as age, gender, education attainment, and income level are identified as determinants affecting farmers' access to formal credit. In addition to age, gender, and education level, Okurut (2006) found that household characteristics such as residence location, family size, and household expenditure also have significant effects on households' access to different types of credit (formal, semi-formal and informal) in South Africa. Vaessen (2001) further pointed out that household access to networks of recommendation/information plays a crucial role in obtaining formal credit by households.

In our study, household variables encompass household demographics (such as age and gender), socioeconomic factors (such as income level and assets ownership) and other household-related factors (such as attitude towards debt and ability to access other sources of credit). Table 1 presents the definitions of variables used in the empirical model.

\section{Insert Table 1 here}

The empirical approach used to analyse accessibility to microcredit from the perspective of rural households is based on binary choice models which describe the probability of households' choice between two mutually exclusive alternatives (accessing or not accessing) according to their evaluations of the utilities of these two choices (Umoh, 2006; Train, 2003). Let $U_{n}\left(Y_{n}, X_{n}\right)$ be the utility function of household $n$, where $Y_{n}$ is a dichotomous variable denoting whether the household has access to microcredit (1 if yes; 0 otherwise); $X_{n}$ is a vector of household characteristics. The household will choose to borrow from microcredit programme if such choice implies a higher utility level compared to not borrowing:

$U_{1 n}\left(Y_{n}=1, X_{n}\right)>U_{0 n}\left(Y_{n}=0, X_{n}\right)$

Consequently, the probability that household $n$ chooses to access microcredit can be written as:

$P_{n}\left(Y_{n}=1\right)=\operatorname{Pr}\left(U_{l n}>U_{0 n}\right)$

Logit model and probit model are two binary choice models commonly used in analysing households' accessibility to credit in the literature. For example, Mohamed (2003) and Vaessen (2001) employed logit model to examine the relative importance of household factors in determining the probability of accessing different types of credit, while Okurut (2006) and Umoh (2006) opted for probti model for their empirical analyses. Both logit and probit models provide consistent, efficient, and asymptotically normal estimates, and yield very similar prediction results in empirical work. Instead of trying to determine the household's choice, this paper utilises the observed information of household's choice (borrow or not borrow) and household's characteristics to estimate the probability of the household's choice conditional on the household characteristics using logit model, owing to the merits possessed by logit model such as approximating the normal distribution quite well and analytical convenience (Train, 2003; Ben-Akiva and Lerman, 1985). The empirical model is specified as follows:

$$
P_{n}\left(Y_{n}=1\right)=1 /\left[1+e^{-\left(\alpha+\beta X_{n}\right)}\right]
$$

where: $Y_{n}$ is dependent variable, equal to 1 if the household has secured microcredit from RCCs and 0 otherwise; $P_{n}$ is the estimated probability of a household having access to microcredit.

Equation (3) represents the cumulative logistic distribution function in a non-linear form, which gives rise to the difficulty in interpreting the coefficients. For the purpose of interpretation, it is normal to write the model in terms of log-odds ratio (Maddala, 2001). With a logit transformation, the estimated model becomes a linear function of the explanatory variables, which is expressed as follows:

$\operatorname{logit}\left[P_{n}\left(Y_{n}=1\right)\right]=\log \left\{P_{n} /\left(1-P_{n}\right)\right\}=\alpha+\beta X_{n}$

where: $\alpha$ is a constant term;

$\beta$ is a vector of coefficients for the independent variables $X_{n}$;

$X_{n}$ is a vector of independent variables (see Table 1), including household's 
demographics, socio-economic characteristics and other household-related factors.

\section{Data collection}

The data include primary data collected through a rural household survey which was personally conducted between November 2008 and January 2009 in Hubei Province in China. Hubei Province is one of the major agricultural provinces in China, where farmers are geographically distributed in both plain areas and mountain areas and take on various agricultural productions such as crop, aquatic products and livestock. There are a total of 1,470 RCC branches located in towns throughout Hubei and at least $60 \%$ have been engaged in micro-financing since RCC initiated microcredit programme in the Province in 2002 (RCC Hubei Head office, 2008). According to the statistics from RCC Hubei Head Office, the amount of micro loans granted to rural households by RCCs has totalled 10.1 billion yuan at the end of 2006 and 4.28 million rural households have obtained micro loans, accounting for $43 \%$ of the total rural households in Hubei.

A structured questionnaire was used to elicit relevant household information, such as age, gender, household size, etc., which is used in the logit model to identify key household-level factors that influence microcredit accessibility among rural population. In addition, the questionnaire gathered qualitative information, such as knowledge of RCC microcredit programme, reasons for not applying for micro loans as well as for loan rejection, etc., for the purpose of investigating the influence of other factors (such as institutional factors) on households' accessibility to microcredit in the descriptive analysis.

A multi-stage stratified random sampling technique was applied to draw the household sample. In the first stage of sampling process, sample townships were selected on the basis of the availability of RCC microcredit programme. A total of 10 townships were selected from the 768 townships hosting RCC's programme, where 3 of the 10 selected townships are located in mountain areas while the rest are situated in plain areas. Following the selection of sample townships, sample villages were selected. A total of 5 villages from every selected township were randomly chosen and altogether 50 villages were included. The selection of sample households was accomplished in the final stage of sampling process. The household selection included two steps: the first step was to select households who have accessed RCC's microcredit (namely borrowers). Based on the borrower list obtained from each RCC branch office in the selected township, a total of 328 borrowers were randomly chosen to participate in the interview. Subsequent to the selection of borrowers, another 96 households who have never secured RCC's microcredit (namely nonborrowers) were randomly selected from a list of rural households obtained from the village committee office in each selected village. Overall, 424 households were included in the sample for the survey and all respondents are heads of households ${ }^{2}$.

\section{Research Results and Discussions}

\section{Characteristics of the rural households}

Table 2 summarises the household characteristics used in the analysis for the whole sample according to the status of respondents' access to microcredit. The t-test is used to test whether the mean values of household variables between borrowers and non-borrowers are statistically different, and the chi-square test is to test the relationship (independent or not) between the nonmetric household variables and access to microcredit. Our results show that the t-test results are not statistically significantly at 10 percent level, except for ASSET. In addition, the households' access to microcredit is strongly associated with GEND, EDU, SELFEMPL, FARMSZ, LOCATN, DIST, SAV, $A T T I T U D$, and ALTER because the chi-square tests on these variables are all significant at the 10 percent level or better.

\section{Insert Table 2 here}

Out of the 424 sampled household heads, 328 are microcredit borrowers of RCC. Our results in Table 2 show that the overall mean age for the sample is around 41 years old and the average age of the borrower and non-borrower respondents is identical. In terms of gender, the sample comprises $332(78.3 \%)$ male household heads and $92(21.7 \%)$ female household heads. Approximately $79.5 \%$ of the sampled male household heads are borrowers of RCC microcredit programme and $69.6 \%$ of the sampled female household heads are engaged in the micro borrowing. However, the borrowers group mainly consist of males.

The survey respondents are divided into three groups with respect to educational attainment, including without education, secondary school education or less, and post-secondary education. The data in Table 2 shows that vast majority of the respondents have obtained some education and only $3.8 \%$ of the respondents reported having no education. The proportion of not being educated for the borrowers is only $1.8 \%$, much lower than that for the non-borrowers $(10.4 \%)$. Around $92.4 \%$ of the borrowers and $80.2 \%$ of the non-borrowers have acquired secondary education or less (including primary, middle and high school). However, in terms of post-secondary education (college and university), the non-borrowers appear to be better educated than the borrowers $(9.4 \%$ versus $5.8 \%)$.

On average the sampled households have 4 family members and the survey results do not show much variation in the average household size between the

\footnotetext{
${ }^{2}$ RCC's micro loans are issued to the households only under the name of household heads, so all borrower respondents are household heads. In order to elicit information from similar perceptions, the non-borrower respondents are also heads from the non-borrowing household.
} 
two groups of households. Only a small portion $(24.3 \%)$ of the respondents is engaged in selfemployment as evidenced by our survey results. The results also suggest that the borrower respondents are more likely to take up self-business compared to the non-borrower respondents (26.5\% versus $18.7 \%)$. The $\chi^{2}$ test (equals 3.92) indicates a strong association between households' access to microcredit and selfemployment engagement (see Table 2).

The economic dependency ratio (EDR), calculated as the ratio of household members without income to household income earners, reflects the economic activity of a household. Households with higher EDRs will be more financially stressed than those with lower ratios. According to this ratio, the non-borrowing households appears to be relatively more economic active than the borrowing households because the proportion of non-borrowing households with EDRs higher than 1.0 is lower than that of the borrowing households (16.7 versus 22.6). The t-test (equals -0.73) does not suggest a significant mean difference between the two group households.

A total of 323 respondents $(76.2 \%)$ rely on agriculture (crop farming, raising livestock, fishery, etc.) as their major source of income while only 14 of the respondents $(3.3 \%)$ are engaged in non-agricultural income-generating activities. Approximately $22.3 \%$ of the borrowing households earn income from both agricultural and non-agricultural activities, whereas $14.6 \%$ of the non-borrowing households source their income from non-agricultural activities in addition to agriculture production. The average annual income and assets value for the sampled household is 47,920 yuan and 12,592 yuan respectively. The t-test further indicates a significant mean difference (at the 5 percent level) in the household assets value between the borrowers and non-borrowers (see Table 2).

All of the respondents do not own farmland. The overwhelming majority $(91.7 \%)$ of the respondents contract their farming land from villages while $8.3 \%$ farm on the leased land. In terms of farm size, up to three quarters of the respondents work on farms no larger than 10 mus. In addition, the proportion of the borrowing households who work on large farms (size larger than 10 mus) is $29 \%$, which is more than two times higher than that of the non-borrowing households $(13.5 \%)$. This implies that households with larger farm sizes are more likely to become RCC's microcredit borrowers.

The geographic distribution of the respondents in Table 2 shows that nearly two thirds of the non-borrowing households live in mountain regions. In addition, the proportion of the borrowing households who live within 10 lis from the RCC branches is higher than that of the non-borrowing households (62.5 versus 52.1) and the share of the borrowers living more than 20 lis from the RCC branches is lower compared to the nonborrowers (4.6 versus 15.6). This suggests that households who live physically closer to the RCC branches are more likely to access RCC's microcredit.
Less than half of the respondents have saving accounts in RCC branches. Compared to the borrowers, the non borrowers appear to be more inclined to deposit money with RCCs (61.5\% versus $42.4 \%)$. In addition, majority (78.3\%) of the respondents do not hold RCCs shares with relatively higher proportion $_{3}$ of shareholding observed in the non-borrower group . Similarly, only a small portion $(13.4 \%)$ of the respondents has one or more family members working as government official(s). About $14.6 \%$ of the non-borrowing households have family member(s) with official status, which is slightly higher than that of the borrowing households $(13.1 \%)$.

Finally, the frequency distributions of ATTITUD and ALTER in Table 2 show that the non-borrower respondents are generally more averse to having debt and more able to access alternative credit sources when they need to borrow, compared to the borrower respondents.

\section{Determinants of household accessibility to microcredit in China}

Logistic regression (equation 3) is conducted to investigate household-level factors that influence households' accessibility to microcredit and estimated via maximum likelihood estimation technique. Table 3 presents the estimated results of the logistic model.

\section{Insert Table 3 here}

Overall the logistic model successfully predicts the possibility of households' microcredit access (82.31 percent). The likelihood ratio test with chi-square statistic equal to 130 with 18 degrees of freedom fails to accept the null hypothesis that the parameter estimates for the model are equal to zero, at the 1 percent level of significance. It can be concluded that the explanatory power of the logistic model is satisfactory and the model can be used to explain the probability of accessing RCC's microcredit by the rural households.

Based on the estimated results, twelve variables are found to have significant influence on households' accessibility to RCC's microcredit, including DIST2, HHSZ, EDU1, INCOME, SELFEMPL, EDR, ASSET, SAV, ATTITUD, ALTER, OFFICIAL and SHAREHLD.

The significant positive sign on INCOME variable indicates that households with higher annual income have higher probability of accessing RCC microcredit. One possible reason for this result is that high income households tend to have more investment opportunities, leading to stronger potential need of credit support. High-income households may also be more confident in repaying loans if they borrow. Therefore, they are more inclined to access microcredit. On the contrary, the significant negative

\footnotetext{
${ }^{3}$ RCC was established in the late 1950s with funds invested by rural households as its establishment funding. Since then RCC has maintained this tradition and encouraged rural household to buy shares. Households who have shares in RCC then become shareholders of RCC.
} 
sign on ASSET variable implies that households' accessibility to microcredit decreases with increased assets values. This is because assets correspond to household initial capital. The households with higher assets values may be less budget constrained and therefore less likely to borrow from microfinance institutions (MFIs) such as RCCs.

The significant positive sign on EDUI dummy variable indicates that households who have acquired secondary school education or less have higher probability to access microcredit than the uneducated households, holding other factors constant. This relationship is expected because farmers with formal education (for example, secondary or post-secondary school) are likely to have more exposure to the external environment including risks and possess more skills, and therefore they might require more credit for consumption and/or production, compared to the uneducated farmers. In contrast, a significant but negative relationship is found between variable $\mathrm{HHSZ}$ and households' accessibility to microcredit, suggesting that the larger-size households are less likely to borrow from RCC's microcredit programme. This is possibly because larger-size households tend to have low repayment capacity resulting from the smaller future expected income per capita, which lowers the probability of borrowing. This finding contradicts to Ho (2004) and Vaessen's (2001) findings who conclude that the probability of accessing formal credit increases with household size.

The estimated coefficients of variables DIST2, ATTITUD, and ALTER are all negative and significantly different from zero at the 1 percent level. Holding other factors constant, the households residing more than 20 lis from RCC branches have significantly lower probability to access RCC microcredit compared to those who live within 10 lis from RCC branches, mainly due to the perceived high borrowing costs arising from the travelling expenses and time opportunity costs. In addition, an adverse attitude towards having debt could decrease the likelihood of accessing any type of credit by households, including microcredit. Furthermore, the availability of other credit sources (such as informal credit) also tends to reduce the probability of borrowing from RCC microcredit programme. This finding is consistent with Vaessen (2001) who observes that many poor households are more willing to use informal credit owing to low transaction costs and flexible loan contracts.

The positive and significant sign on variable SELFEMPL indicates that the probability of accessing microcredit can be significantly improved when households get involved in self-business apart from agriculture production. This can be explained by the higher capital requirement for investing in self enterprises. The results show that official status (OFFICIAL) is also a contributor to households' access to microcredit. One possible reason is that households with members working as village or township officials have greater need of credit for off-farm investment and thus have higher probability of accessing microcredit.
Households with members working as local officials may also access RCC's microcredit easier due to their good relationship with the local financial institutions such as RCC.

Variables EDR, SAV, and SHAREHLD are found to significantly influence households' accessibility to microcredit in an unexpected way. The estimated coefficient of EDR is positive, implying that the households who are less economic active have higher probability of being engaged in RCC microcredit programme. One possible explanation for this unexpected relationship is that households with higher dependency ratios have less family members taking up income-generating activities and thus are more inclined to rely on loans for household activities such as consumption and children education due to insufficient income. As a result, they are more likely to access RCC's microcredit. The inverse relationship between $S A V$ and households' accessibility suggests that households who deposit money with RCCs have lower probability to access RCC's microcredit. This is possible since these households are able to access their savings in RCCs when they need financial support, which in turn weaken the likelihood of borrowing micro loans from RCC. Similarly, the households who bought shares of RCC are likely to have more surplus money in their own control, which reduces their intentions to borrow. This might account for the negative relationship between SHAREHLD and households' access to RCC's microcredit.

The marginal effects are also calculated for the regressors of the logit model to provide a direct economic interpretation on the influence of these variables on households' accessibility to microcredit. The results are also summarised in Table 3. For example, the marginal effect of HHSZ indicates that an additional member increase in the family would decrease the probability of accessing microcredit by 2.36 percent on average. In addition, the probability of borrowing from RCC microcredit programme would increase by 0.12 percent with every 1,000 yuan increase in INCOME. By contrast, an additional 1,000 yuan increase in ASSET would reduce households' probability of accessing RCC microcredit by 0.64 percent. This however indicates that the marginal effects of both INCOME and ASSET on the probability of accessing microcredit are minimal. Furthermore, the marginal effect of SELFEMPL shows that being engaged in self employment would enhance the probability of borrowing from the programme by 5.47percent. Similarly, the probability of accessing microcredit for households with members working as local officials increases by 7.24 percent. However, the marginal effects of ATTITUD and ALTER suggest that the probability of accessing microcredit would decrease by 16.76 percent when the household holds a negative attitude towards debt, and by 10.02 percent when the household can find alternative credit sources other than RCC microcredit.

\section{Other factors affecting households, accessibility to microcredit}


Some qualitative information was also gathered from the household survey to investigate factors affecting the households' access to microcredit in rural China, other than those empirically analysed.

\section{Knowledge of RCC microcredit programme}

From the 96 non-borrower respondents, 28 respondents reported that they had no knowledge about the microcredit programme operated by RCC. Three main reasons are found in such lack of knowledge. One of the most cited reasons is the lack of understanding of the concept 'microcredit' $(60.7 \%)$. This is followed by the inadequate promotion of microcredit programme by RCC $(21.4 \%)$ and the unawareness of the RCC branches nearby $(17.9 \%)$.

\section{Need to borrow}

The survey results show that $77 \%(n=74)$ of the total non-borrower respondents had no need to borrow money in the past two years. This further confirms that credit demand determines households' access to microcredit to a large extent. For the other 22 nonborrowers who signalled credit needs, 18 had applied for micro loans from RCCs but rejected, and 4 had resorted to either formal lenders (e.g., Agricultural Bank of China) or informal lenders (e.g., friends, relatives).

\section{Reasons for loan rejection}

The 18 non-borrower respondents whose loan applications were rejected were asked to provide reasons why they were denied loans. The result reported that ten $(55.6 \%)$ of the respondents attributed the loan rejections to their poor repayment capacity arising from low household income. Inability to provide loan security (e.g., collateral or co-signer) was also mentioned by 10 of the respondents as an adverse factor in their loan application. Moreover, 33\% of the respondents deemed their failure in securing micro loans as a result of their blemished credit history caused by previous loans defaults. This implies that creditworthiness potentially impacts the households' access to microcredit. Furthermore, $28 \%$ of the respondents report that the difficulty in meeting the required documents by the RCC loan officers also prevented them from accessing microcredit.

\section{Reasons for not applying micro loans}

All the non-borrower respondents $(n=96)$ were asked whether they need to borrow in the future and if they have to, would they apply for micro loans from RCCs. The result reported that 83 of the non-borrowers signalled borrowing intention in the future, of whom 53 expressed that they would give priority to RCC micro loans if they have credit needs. The remaining 30 respondents who indicated unwillingness to access RCC's microcredit programme were further asked to provide reasons why they do not borrow from RCC. Income is found to be a determinant in the households' future borrowing from RCC microcredit programme. The result reported that $66.7 \% \quad(n=20)$ of the households would not borrow because their meagre income is not sufficient to repay loans. In addition,
$50 \%(n=15)$ of the respondents mentioned that the interest rate of RCC micro loans is set too high to afford, which is another crucial factor that restrains the households from applying micro loans. Similarly, 15 non-borrower respondents prefer informal loans over RCC micro loans because the former can be easily obtained. Other reasons include complicated application procedure adopted by RCC in terms of documents requirement and processing time (43.3\%), lack of proper collateral $(33.3 \%)$, and poor credit records $(26.7 \%)$.

\section{Conclusions}

This study examines the key factors that influence the accessibility of microcredit by rural households in China. Overall, our results suggest that rural households (especially the poor) and women in China have limited access to institutional credit including the microcredit provided by RCC. The empirical analysis based on the logistic regression has established twelve household-level factors important in affecting households' likelihood to access microcredit, including household size, educational level, distance, income, assets value, being self-employed, economic dependency ratio, savings, official status, shareholding status, attitude towards debt, and access to alternative credit sources. Household income, self-employment and official status are three contributors to households' accessibility to microcredit because a higher credit demand resulting from the higher capital requirement (on/off farm), raises the likelihood of accessing microcredit by households. Conversely, household assets and savings can be used as proxies for household initial capital, and a higher value of either of them can potentially decrease the probability of accessing microcredit by the households. Households with large family size would be less likely to access microcredit programme due to the perceived low repayment capacity arising from the smaller future expected income per capita. Similarly, the probability of accessing microcredit would be substantially reduced if the households are averse to have debt or can access alternative credit sources.

As documented in this study, the heterogeneous nature of rural households is essential in accounting for the differential opportunities of accessing microcredit, and therefore, simply expanding microcredit programmes in rural areas may be inadequate to increase credit access by the rural households. On the demand side, the limited credit access can be largely attributed to the low or lack of credit demand by the rural households for either agricultural production or off-farm activities, where the demand for credit is determined by a number of household-related factors such as those identified in this study. In addition, poor households have restricted access to microcredit because they effectively ration themselves out of the credit market for the reasons such as inability to provide collateral and low repayment ability arising from their poor wealth situations. One efficient way of facilitating households' access to microcredit is to encourage households to create investment opportunities in on/off farm activities (see Cheng, 2006). This will give rise to additional capital 
requirement, which potentially increases households' demand for credit.

In addition to the demand-side factors, our analysis indicates that the supply-side factors such as interest rates, documents requirement, and loan processing time cam impair households' access to microcredit. Therefore, microfinance institutions (MFIs) such as RCC should improve its micro lending policies (such as simplifying lending procedures) and re-design its micro loan products that allow for more flexible terms and conditions to better suit the diverse needs of the local rural households. These innovations (especially client-responsive loan products) are deemed to be more desirable by the poor whose living conditions are generally associated with uncertainty and vulnerability because these flexible services can help them better deal with risks and thus reduce vulnerability. Another observation in this study is that the households' inadequate access to microcredit can be due to their poor knowledge of RCC's microcredit programme. Thus, to improve households' accessibility to microcredit, there is an imperative for MFs to enhance promotion of their microcredit programmes among the rural households and make the households fully aware of the features of microcredit (e.g., collateral free). This can be done through village meetings (or social gatherings) and mass media such as radio and newspaper.

The strong link between repayment capacity (perceived by the households) and access to microcredit indicates that increasing households' repayment capacity helps improve their access to microcredit. Hence, it is important for MFs to combine micro loans with other services or products that help improve the efficiency of loan use, which in turn helps build up the households' confidence in repaying loans. A useful service is to provide borrowing households with the evaluation of profitability of the loan-supported projects. Other services may include agricultural technical extension, off-farm business introduction and training in cash flow and risk management.

Our findings indicate that informal credit plays an important role in meeting the credit needs of the Chinese rural households. This includes not only households who fail to obtain financial support through formal channels (such as RCC's microcredit programme), but also those who may be able to obtain formal credit but choose to borrow from informal lenders due to the potential merits of informal lenders (example, flexible lending schemes). This implies that the existence of informal finance may not simply be a result of insufficient supply of formal credit or credit rationing by formal institutions. It is likely that the different lending approaches adopted by formal and informal lenders make them cater to distinct groups of borrowers with various concerns. This is another main reason for the persistent co-existence of formal and informal finance in many developing countries including China.
Policymakers in China should re-evaluate the role of informal financial sector in rural credit delivery and formulate new policies regarding the development of informal finance. For example, rather than trying to eliminate the informal finance, it would be more appropriate to reinforce the linkages between the formal and informal financial sectors in China. Better linkages between the two sectors enable one sector to overcome its own weaknesses by drawing from the other's strengths, such as banks can make use of the outreach and local knowledge of informal lenders while informal lenders can benefit from formal lenders' strong resource mobilisation ability and wide networks across the region. Consequently, strengthening the association between the formal and informal sectors helps expand credit delivery and improve the overall efficiency of the financial system, and hence, accelerates the development of China rural economy.

\section{References}

Atieno, R. (2001) Formal and informal institutions' lending policies and access to credit by small-scale enterprises in Kenya: an empirical assessment. Nairobi, Kenya: The African Economic Research Consortium.

Ayyagari, M., Demirguc-Kunt, A. and Maksimovic, V. (2008) Formal versus informal finance: evidence from China. World Bank Policy Research Working Paper Series 4465.

Ben-Akiva, M. and Lerman, S. (1985) Discrete choice analysis: theory and application to travel demand. Cambridge, Mass: MIT Press.

Brau, J. C. and Woller, G. M. (2004) Microfinance: A comprehensive review of the existing literature. Journal of Entrepreneurial Finance and Business Ventures 9, pp.1-26.

Cheng, E. J. (2006) The demand for micro-credit as a determinant for microfinance outreach - evidence from China. Paper presented at ACESA Annual Conference on 'Emerging China: Internal Challenges and Global Implications', Melbourne, Australia, 13-14 July 2006.

Cheng, E. J. and Xu, Z. (2004) Rates of interest, credit supply and China's rural development. Savings and Development 2, pp.131-156.

Diagne, A. (1999) Determinants of household access to and participation in formal and informal credit markets in Malawi. Food Consumption and Nutrition Division Discussion Paper No. 67, International Food Policy Research Institute, Washington, D.C.

Diagne, A. and Zeller, M. (2001) Access to credit and its impact on welfare in Malawi. International Food Policy Research Institute Research Report 116.

Druschel, K. (2002) Microfinance in China: building sustainable institutions and a strong industry. Master's thesis, School of International Service, American University. Available at www.american.edu/sis/idp/resources/Druschel\%20SRP .pdf

Du, X. S. (2004) Attempts to implement micro-finance in rural China. In Organisation for Economic Co- 
operation and Development (OECD), Centre for Cooperation with Non-members, Rural finance and credit infrastructure in China (pp. 271-284). Paris: OECD Publications.

Du, X. S. (2005) The regulatory environment for microfinance in China. Essays on Regulation and Supervision, No. 11. Available at

www.microfinancegateway.org/redirect.php?mode=lin $\underline{\mathrm{k} \& \mathrm{id}=25978}$

Evans, T. G., Adams, A. M. and Mohammed, R. (1999) Demystifying nonparticipation in microcredit: a population-based analysis. Journal of World Development 27(2), pp.419-430.

Gale, F. and Collender, R. (2006) New directions in China's agricultural lending. The Economic Research Service Electronic Outlook Report WRS-06-01. United States Department of Agriculture (USDA). Available at www.ers.usda.gov/publications/WRS0601/WRS0601.p $\underline{\mathrm{df}}$

Gale, F., Lohmar, B. and Tuan, F. (2005) China's new farm subsidies. The Economic Research Service Electronic Outlook Report WRS-05-01. United States Department of Agriculture (USDA). Available at http://chinese.hongkong.usconsulate.gov/uploads/imag es/G3YqRBpWgqBIVX0ef2Kqvg/uscn_t_usda_2005w rs0501.pdf

Guo, X. M. and Lei, X. M. (2000) Credit. In J. M. Xiong (ed.) Rural China Entering the 21st Century. Beijing, China: Guangming Daily News Publishing.

Han, J. (2004) The creation of a favourable environment for investment in rural China: current situation and future prospects. In Organisation for Economic Co-operation and Development (OECD), Centre for Co-operation with Non-members, Rural finance and credit infrastructure in China (pp. 23-33). Paris: OECD Publications.

He, G. W. and Guo, P. (2004) Rational Thoughts on the Reform of Rural Policy Finance. Issues in Agricultural Economy 3, pp.1-17.

Ho, G. (2004) Rural Credit Markets in Vietnam: theory and practice. Grand prize thesis, Macalester College. Available at http://aede.osu.edu/resources/docs/pdf/DS7C7NV6KC9D-AV0O-PN7BPPG0KGTY7WWW.pdf

Jia, X. P., Heidhues, F. and Zeller, M. (2007) Taking the hands off the rural credit market: An evidence from China. Studies on the Agricultural and Food Sector in Central \& Eastern Europe 39, pp.164-180.

Klein, B., Meyer, R., Hannig, A., Burnett, J. and Fiebig, M. (1999) Better practice in agricultural lending. Agricultural Finance Revisited (AFR) No. 3, Food and Agriculture Organisation of the United Nations (FAO).

Ma, X. H. (2004) The difficulties and policy reform in China's rural finance. In Organisation for Economic Co-operation and Development (OECD), Centre for Co-operation with Non-members, Rural finance and credit infrastructure in China (pp. 87-96). Paris: OECD Publications.

Maddala, G. S. (2001) Introduction to econometrics. Chichester; New York: John Wiley.

Maes, J. and Foose, L. (2006) Microfinance services for very poor people: promising approaches from the field. Paper commissioned by the 2006 Annual Microcredit Summit Campaign. Available at http://www.microcreditsummit.org/commissioned_pap ers/

Mohamed, K. (2003) Access to formal and quasiformal credit by smallholder farmers and artisanal fishermen: a case of Zanzibar. Dar es Salaam, Tanzania: Research on Poverty Alleviation (REPOA).

Okurut, F. N. (2006) Access to credit by the poor in South Africa: evidence from household survey data 1995 and 2000. University of Stellenbosch Working Papers 13/06.

Park, A., Ren, C. Q., and Wang, S. G. (2004) Microfinance, poverty alleviation, and financial reform in China. In Organisation for Economic Co-operation and Development (OECD), Centre for Co-operation with Non-members, Rural finance and credit infrastructure in China (pp. 256-270). Paris: OECD Publications.

Rural Credit Cooperative Hubei Head office (RCCHHO). (2008) The guide on the management of RCC's rural microcredit in Hubei Province. Hubei, China: RCCHHO. (in Chinese)

The People's Bank of China. (2001) Guidelines on rural household micro-credit by rural credit cooperatives. Available at

http://www.cgap.org/regsup/docs/law_China 04.pdf

Tilakaratna, S. (1996) Credit schemes for the rural poor: Some conclusions and lessons from practice. International Labour Office Issues in Development Discussion Paper 9.

Train, K. (2003) Discrete choice methods with simulation. Cambridge, UK: Cambridge University Press.

Umoh, G. S. (2006) Empirical investigation of access to micro-credit in an emerging economy: evidence from Nigeria. Journal of African Business 7 (1/2), pp.89-117.

Unger, J. (2002) Poverty, credit and microcredit in rural China. Development Bulletin 57, pp.23-26.

Vaessen, J. (2001) Accessibility of rural credit in Northern Nicaragua: the importance of networks of information and recommendation. Savings and development 25(1), pp.5-32.

Wang, R. X. and Liu, X. M. (2005) Problems of China's rural financial system. In L. Söderlund, J. Sippola \& M. Kamijo-Söderlund(Eds), Proceedings of SUSDEV - CHINA Symposium. Jokioinen, Finland: MTT Agrifood Research Finland, Data and Information Services. 
Zeller, M. (1994) Determinants of credit rationing: A study of informal lenders and formal credit groups in Madagascar. World Development 22 (12), pp.18951907. 
Table 1 Description of Variables Used in Logit Model

\begin{tabular}{|c|c|c|}
\hline Variable Name & Variable Type & Variable Description \\
\hline \multicolumn{3}{|l|}{ Demographics } \\
\hline$A G E$ & Continuous & Age of household head (in years) \\
\hline GEND & Binary & Gender of household head $(1=$ female, $0=$ male $)$ \\
\hline HHSZ & Continuous & Household size (in numbers) \\
\hline$E D U$ & & Educational level of household head \\
\hline$E D U 1$ & Binary & $1=$ without education, 0 otherwise \\
\hline$E D U 2$ & Binary & $1=$ secondary school or less, 0 otherwise \\
\hline$E D U 3$ & Binary & $1=$ post-secondary education, 0 otherwise \\
\hline \multicolumn{3}{|l|}{ Socio-economics } \\
\hline INCOME & Continuous & Household annual income (in 1,000 yuan ${ }^{\mathrm{a}}$ ) \\
\hline ASSET & Continuous & Total value of household assets ${ }^{\mathrm{d}}$ (in 1,000 yuan) \\
\hline FARMSZ & Binary & $\begin{array}{l}\text { Size of household farmland ( } 1=10 \text { mus }{ }^{b} \text { or less, } 0 \\
\text { otherwise) }\end{array}$ \\
\hline$E D R$ & Continuous & $\begin{array}{l}\text { Ratio of household members without income to household } \\
\text { income earners }\end{array}$ \\
\hline SELFEMPL & Binary & $\begin{array}{l}\text { Household head's involvement in self-employment }(1= \\
\text { yes, } 0 \text { otherwise) }\end{array}$ \\
\hline OFFICIAL & Binary & $\begin{array}{l}\text { Family members working as village or township officials } \\
(1=\text { yes, } 0 \text { otherwise })\end{array}$ \\
\hline SHAREHLD & Binary & Household owning shares of RCC ( $1=$ yes, 0 otherwise) \\
\hline$S A V$ & Binary & Household savings with RCC ( $1=$ yes, 0 otherwise $)$ \\
\hline \multicolumn{3}{|l|}{ Other variables } \\
\hline LOCATN & Binary & $\begin{array}{l}\text { Geographic location of household residence }(1= \\
\text { mountainous area, } 0 \text { otherwise })\end{array}$ \\
\hline DIST & & $\begin{array}{l}\text { Distance between household residence and RCC branch } \\
\text { office }\end{array}$ \\
\hline DIST1 & Binary & $1=$ within $10 \operatorname{lis}^{\mathrm{c}}, 0$ otherwise \\
\hline DIST2 & Binary & $1=$ between 11 and 20 lis, 0 otherwise \\
\hline DIST3 & Binary & $1=$ more than 20 lis, 0 otherwise \\
\hline ALTER & Binary & Access to other credit sources $(1=$ yes, 0 otherwise $)$ \\
\hline ATTITUD & Binary & Attitude towards debt ( $1=$ averse, 0 otherwise $)$ \\
\hline
\end{tabular}

Notes: $\quad$ a. 1 US $\$ \approx 6.8265$ yuan;

b. $m u$ is the common area measurement in rural China. $1 \mathrm{mu} \approx 0.067 \mathrm{ha}$;

c. $l i$ is the common distance measurement in rural China. $1 \mathrm{li} \approx 0.5 \mathrm{~km}$

d. the household asset values exclude house values and farmland values. 
Table 2 Profile of the Respondents (Borrowers and Non-borrowers)

\begin{tabular}{|c|c|c|c|c|c|c|c|}
\hline & \multicolumn{2}{|c|}{$\begin{array}{c}\text { Non-Borrower } \\
\left(\mathrm{N}_{1}=96\right)\end{array}$} & \multicolumn{2}{|c|}{$\begin{array}{c}\text { Borrower } \\
\left(\mathrm{N}_{2}=328\right)\end{array}$} & \multicolumn{2}{|c|}{$\begin{array}{c}\text { All respondents } \\
\left(\mathrm{N}_{3}=424\right)\end{array}$} & \multirow[t]{2}{*}{$\begin{array}{c}\text { Statistical } \\
\text { test }\end{array}$} \\
\hline & $\begin{array}{c}\text { Count } \\
\left(\mathrm{n}_{1}\right)\end{array}$ & $\%$ to $\mathrm{N}_{1}$ & $\begin{array}{c}\text { Count } \\
\left(\mathrm{n}_{2}\right)\end{array}$ & $\%$ to $\mathrm{N}_{2}$ & $\begin{array}{c}\text { Sub-total } \\
\left(\mathrm{N}_{4}=\mathrm{n}_{1}+\mathrm{n}_{2}\right)\end{array}$ & $\%$ to $\mathrm{N}_{4}$ & \\
\hline \multicolumn{8}{|l|}{ Demographics } \\
\hline \multicolumn{8}{|l|}{ GEND } \\
\hline Male & 68 & 70.8 & 264 & 80.5 & 332 & 78.3 & $\chi^{2}=4.07^{* *}$ \\
\hline Female & 28 & 29.2 & 64 & 19.5 & 92 & 21.7 & \\
\hline Total & & 100.0 & & 100.0 & & 100.0 & \\
\hline \multicolumn{8}{|l|}{$E D U$} \\
\hline No education & 10 & 10.4 & 6 & 1.8 & 16 & 3.8 & $\chi^{2}=17.183^{* * *}$ \\
\hline Secondary school or less & 77 & 80.2 & 303 & 92.4 & 380 & 89.6 & \\
\hline Post secondary & 9 & 9.4 & 19 & 5.8 & 28 & 6.6 & \\
\hline Total & & 100.0 & & 100.0 & & 100.0 & \\
\hline$A G E$ & \multicolumn{2}{|c|}{41.02} & \multicolumn{2}{|c|}{41.28} & \multicolumn{2}{|c|}{41.22} & $\mathrm{t}=-0.22$ \\
\hline$\overline{H H S Z}$ & \multicolumn{2}{|c|}{4.18} & \multicolumn{2}{|c|}{4.16} & \multicolumn{2}{|c|}{4.17} & $t=0.12$ \\
\hline \multicolumn{8}{|l|}{ Socio-economics } \\
\hline \multicolumn{8}{|l|}{ SELFEMPL } \\
\hline Yes & 16 & 18.7 & 87 & 26.5 & 103 & 24.3 & $\chi^{2}=3.92^{* *}$ \\
\hline No & 80 & 83.3 & 241 & 73.5 & 321 & 75.7 & \\
\hline Total & & 100.0 & & 100.0 & & 100.0 & \\
\hline \multicolumn{8}{|l|}{$\overline{E D R}(r)$} \\
\hline $\mathrm{r}<=1$ & 80 & 83.3 & 254 & 77.4 & 334 & 78.8 & \\
\hline$r>1$ & 16 & 16.7 & 74 & 22.6 & 90 & 21.2 & \\
\hline Total & & 100.0 & & 100.0 & & 100.0 & \\
\hline Mean & \multicolumn{2}{|c|}{0.84} & \multicolumn{2}{|c|}{0.90} & \multicolumn{2}{|l|}{0.4} & $t=-0.73$ \\
\hline INCOME (in yuan) & & & & 19 & 47,92 & & $\mathrm{t}=-1.19$ \\
\hline Main income sources & & & & & & & \\
\hline Agriculture & 77 & 80.2 & 246 & 75.0 & 323 & 76.2 & $\chi^{2}=3.76$ \\
\hline Non-agriculture & 5 & 5.2 & 9 & 2.7 & 14 & 3.3 & \\
\hline Both & 14 & 14.6 & 73 & 22.3 & 87 & 20.5 & \\
\hline Total & & 100.0 & & 100.0 & & 100.0 & \\
\hline$\overline{A S S E T \text { (in yuan) }}$ & & & & 78 & 12,59 & & $\mathrm{t}=2.46^{* * *}$ \\
\hline Land Holding Status & & & & & & & \\
\hline Contracted & 85 & 88.5 & 304 & 92.7 & 389 & 91.7 & $\chi^{2}=2.23$ \\
\hline Leased & 11 & 11.5 & 24 & 7.3 & 35 & 8.3 & \\
\hline Total & & 100.0 & & 100.0 & & 100.0 & \\
\hline$\overline{F A R M S Z}($ in $\mathrm{mu})$ & & & & & & & \\
\hline 10 or less & 83 & 86.5 & 233 & 71.0 & 316 & 74.5 & $\chi^{2}=9.30^{* * *}$ \\
\hline More than 10 & 13 & 13.5 & 95 & 29.0 & 108 & 25.5 & \\
\hline Total & & 100.0 & & 100.0 & & 100.0 & \\
\hline Other Characteristics & & & & & & & \\
\hline$\overline{L O C A T N}$ & & & & & & & \\
\hline Mountainous & 62 & 64.6 & 164 & 50.0 & 226 & 53.3 & $\chi^{2}=6.35^{* *}$ \\
\hline Non-mountainous & 34 & 35.4 & 164 & 50.0 & 198 & 46.7 & \\
\hline Total & & 100.0 & & 100.0 & & 100.0 & \\
\hline$\overline{D I S T}$ (in li) & & & & & & & \\
\hline $1-10$ & 51 & 53.1 & 205 & 62.5 & 256 & 60.4 & $\chi^{2}=13.97^{* * *}$ \\
\hline $11-20$ & 30 & 31.3 & 108 & 32.9 & 138 & 32.5 & \\
\hline$>20$ & 15 & 15.6 & 15 & 4.6 & 30 & 7.1 & \\
\hline Total & & 100.0 & & 100.0 & & 100.0 & \\
\hline$S A V$ & & & & & & & \\
\hline Yes & 59 & 61.5 & 139 & 42.4 & 198 & 46.7 & $\chi^{2}=10.86^{* * * *}$ \\
\hline No & 37 & 38.5 & 189 & 57.6 & 226 & 53.3 & \\
\hline Total & & 100.0 & & 100.0 & & 100.0 & \\
\hline
\end{tabular}


Table 2 Profile of the Respondents (Cont)

\begin{tabular}{|c|c|c|c|c|c|c|c|c|}
\hline SHAREHLD & & & & & & & & \\
\hline & Yes & 29 & 30.2 & 63 & 19.2 & 92 & 21.7 & $\chi^{2}=5.29^{* *}$ \\
\hline & No & 67 & 69.8 & 265 & 80.8 & 332 & 78.3 & \\
\hline & Total & & 100.0 & & 100.0 & & 100.0 & \\
\hline$\overline{O F F I C I A L}$ & & & & & & & & \\
\hline & Yes & 14 & 14.6 & 43 & 13.1 & 57 & 13.4 & $\chi^{2}=0.14$ \\
\hline & No & 82 & 85.4 & 285 & 86.9 & 367 & 86.6 & \\
\hline & Total & & 100.0 & & 100.0 & & 100.0 & \\
\hline$\overline{A T T I T U D}$ & & & & & & & & \\
\hline & aversion & 54 & 56.3 & 79 & 24.1 & 133 & 31.4 & $\chi^{2}=35.69^{* * *}$ \\
\hline & others & 42 & 43.7 & 249 & 75.9 & 291 & 68.6 & \\
\hline & Total & & 100.0 & & 100.0 & & 100.0 & \\
\hline ALTER & & & & & & & & \\
\hline & Yes & 88 & 91.7 & 188 & 57.3 & 276 & 65.1 & $\chi^{2}=38.56^{* * *}$ \\
\hline & No & 8 & 8.3 & 140 & 42.7 & 148 & 34.9 & \\
\hline & Total & & 100.0 & & 100.0 & & 100.0 & \\
\hline
\end{tabular}

Note: $\quad$ Entries for variables $A G E, H H S Z, I N C O M E$ and $A S S E T$ are mean values;

$*^{* * *}$, and ${ }^{* * *}$, represent $10 \%, 5 \%$, and $1 \%$ significant level, respectively. 
Table 3 Logit Estimates for Households’ Accessibility to Microcredit

\begin{tabular}{|c|c|c|c|c|}
\hline Independent Variables $^{1 /}$ & $\begin{array}{c}\text { Estimated } \\
\text { Coefficients }\end{array}$ & $\begin{array}{l}\text { Standard } \\
\text { Error }\end{array}$ & $\begin{array}{c}\text { Wald } \\
\text { Statistics }\end{array}$ & $\begin{array}{c}\text { Marginal } \\
\text { Effect }^{2 /}\end{array}$ \\
\hline$\overline{\mathrm{AGE}}$ & 0.0103 & 0.0191 & 0.2874 & 0.0011 \\
\hline GEND & -0.3710 & 0.3288 & 1.2726 & -0.0437 \\
\hline LOCATN & -0.4565 & 0.4477 & 1.0398 & -0.0392 \\
\hline HHSZ & $-0.2262^{*}$ & 0.1356 & 2.7851 & -0.0236 \\
\hline FARMSZ & 0.7010 & 0.4375 & 2.5667 & 0.0548 \\
\hline SELFEMPL & $0.7000^{* *}$ & 0.3605 & 3.7672 & 0.0547 \\
\hline EDR & $0.5353^{* *}$ & 0.2255 & 5.6339 & 0.0558 \\
\hline INCOME (in 1,000 yuan) & $0.0117^{* *}$ & 0.0059 & 3.8842 & 0.0012 \\
\hline ASSET (in 1,000 yuan) & $-0.0617^{* *}$ & 0.0303 & 4.1265 & -0.0064 \\
\hline SAV & $-1.2124^{* * *}$ & 0.3624 & 11.1588 & -0.1895 \\
\hline ATTITUD & $-1.1050^{* * *}$ & 0.3046 & 13.1609 & -0.1676 \\
\hline ALTER & $-2.1137^{* * *}$ & 0.4512 & 21.9483 & -0.1002 \\
\hline OFFICIAL & $1.0596^{* *}$ & 0.4707 & 5.0668 & 0.0724 \\
\hline SHAREHLD & $-1.0391^{* * *}$ & 0.3694 & 7.9128 & -0.1544 \\
\hline \multicolumn{5}{|l|}{$\begin{array}{l}\text { Dummy variables } \\
\text { (DIST) }\end{array}$} \\
\hline DIST2 & -0.2071 & 0.3162 & 0.4290 & -0.0230 \\
\hline DIST3 & $-1.4804^{* * *}$ & 0.5525 & 7.1785 & -0.2495 \\
\hline \multicolumn{5}{|l|}{ (EDU) } \\
\hline EDU2 & $1.1641^{*}$ & 0.6811 & 2.9214 & 0.1797 \\
\hline EDU3 & 0.6809 & 0.8935 & 0.5808 & 0.0536 \\
\hline Constant & $3.6876^{* * *}$ & 1.4357 & 6.5976 & \\
\hline McFadden R-squared & & & & 0.2878 \\
\hline Log likelihood & & & & -161.5214 \\
\hline LR statistic & & & & $130.5594^{* * *}$ \\
\hline Degree of Freedom & & & & 18 \\
\hline Total observations & & & & 424 \\
\hline \multicolumn{5}{|l|}{ Classification table } \\
\hline & Dependent $=0$ & Dependent $=1$ & \multicolumn{2}{|c|}{ Overall } \\
\hline No. of correct & 39 & 310 & \multicolumn{2}{|c|}{349} \\
\hline$\%$ of correct & 40.63 & 94.51 & \multicolumn{2}{|c|}{82.31} \\
\hline No. of incorrect & 57 & 18 & \multicolumn{2}{|c|}{75} \\
\hline$\%$ of incorrect & 59.38 & 5.49 & \multicolumn{2}{|c|}{17.69} \\
\hline
\end{tabular}

Note: $\quad 1 /$. Dependent variable $=1$ if household has accessed microcredit and zero otherwise;

2/. Marginal effect is at the mean value. For binary variable, marginal effect is $\mathrm{P}|1-\mathrm{P}| 0$;

$3 /$. To avoid multicollinearity problem, a dummy variable is dropped in each group.

******, represent $10 \%, 5 \%$, and $1 \%$ significant level, respectively. 